\title{
Anthelmintic potential and in vivo acute toxicity study of Piptadenia gonoachanta leaf aqueous extract
}

\author{
Mariana Costa Fausto ${ }^{1}$, Idelvânia dos Anjos Nonato ${ }^{1}$, Guilherme Costa Fausto ${ }^{1}$, Rogério Pinto ${ }^{2}$, \\ Fabrício Luciani Valente ${ }^{1}$, Lorendane Millena de Carvalho ${ }^{1}$, Artur Kanadani Campos ${ }^{1}$, \\ Marcelo Barcellos da Rosa ${ }^{3}$, Jackson Vitor de Araújo ${ }^{1}$, Camilo Amaro de Carvalho ${ }^{4}$ \\ ${ }^{1}$ Department of Veterinary Medicine, Federal University of Viçosa, Viçosa, MG, Brazil. \\ ${ }^{2}$ Departament of Pharmacy, Univiçosa, Viçosa, MG, Brazil. \\ ${ }^{3}$ Department of Chemistry, Federal University of Santa Maria, Santa Maria, RS, Brazil. \\ ${ }^{4}$ Department of Medical and Nursing, Federal University of Viçosa, Viçosa, MG, Brazil.
}

\section{ARTICLE INFO}

Article history:

Received on: 20/05/2017

Accepted on: 14/09/2017

Available online: 30/10/2017

Key words:

Anthelmintic activity;

Piptadenia gonoacantha;

Low toxicity; Leguminoseae.

\begin{abstract}
Piptadenia gonoacantha (Leguminosae) is an arboreal species found in southern and southeastern Brazil. Several compounds have been identified in their leaves, such as anthraquinones, phenolics, tannins, saponins, coumarins and flavonoids. The presence of these metabolites is associated with antioxidant, anti-inflammatory, antibiotic and anthelmintic properties. This study evaluated the phytochemical profile of in vitro anthelmintic activity and in vivo toxicity of the aqueous extract of $P$. gonoacantha leaves. The extracts were distinctly evaluated by extraction method: maceration (EAM), ultrasonication (EAU) and lyophilization (EAL). Anthelmintic activity analysis was carried out for all preparations at 25,50 and $100 \mathrm{mg} \cdot \mathrm{mL}^{-1}$ against Panagrellus sp. in an in vitro assay. In vivo toxicity was assessed by biochemical, hematological and histological evaluation of Balb/C mice treated orally with EAU (100, 200 and $\left.400 \mathrm{mg} \cdot \mathrm{Kg}^{-1}\right)$ for 10 consecutive days. Phytochemical analysis showed the presence of tannins, flavonoids, coumarins, saponins, glycosides, phenolic compounds and anthraquinone. Anthelmintic potential showed significant results, with inhibition potential ranging from $93.93 \%$ and $99.88 \%$ among the different concentrations and preparations tested. In absolute values, the EAPG at $50 \mathrm{mg} / \mathrm{mL}$ showed a higher percentage of inhibition, reaching the following concentrations: 25,50 and $100 \mathrm{mg} / \mathrm{mL}$ of preparation I (EAM), 25 and $100 \mathrm{mg} / \mathrm{mL}$ of preparation II (EAU) and 25,50 and $100 \mathrm{mg} / \mathrm{mL}$ of preparation III (EAL), had percentage of inhibition of $99.39 \%, 96.15 \%, 96.57 \%$, $96.45 \%, 95.01 \%, 99.74 \%$ and $99 \% 44 \%$ respectively. EAU has proved to be safe for in vivo use because it showed low toxicity, enabling it to future pre-clinical and clinical studies.
\end{abstract}

\section{INTRODUCTION}

The interest in the use of bioactive plant compounds responsible for therapeutic actions has been an area of growing research (Viegas et al., 2006; Sandoval-Castro et al., 2012). According to the World Health Organization (WHO), $85 \%$ of the population of developing countries uses medicinal plants in

\footnotetext{
* Corresponding Author

Department of Medical and Nursing, Federal University of Viçosa UFV, Av PH Rolfs, s/n, 36570-900, Viçosa, MG, Brazil.

Tel.:+55 313899 3090; fax number: +55 31 3899-3916.

E-mail: camilo.carvalho@ufv.br(C.A. Carvalho).
}

nature or herbal formulations. However, in order to be used for this purpose, it is important to identify which pharmacological principles are present in the vegetal species and whether they have toxic components that could create risks to animal and human health (Simões et al., 2004; Carvalho et al., 2014). Therefore in vivo and in vitro tests must be performed to evaluate their effects (Mellor, 2000). Although the chemical and pharmaceutical industries have produced a wide variety of drugs in recent years, there is an increase in microorganism resistance. This fact encourages the search for alternative sources such as herbal substances with antimicrobial and antiparasitic activity (Ribeiro, 2008; Padilha et al., 2010). 
Scarce knowledge about parasite survival mechanisms and the decrease of investments in innovative anti-parasitic molecules diminish the development of new effective chemical groups in parasitosis control (Geary and Thompson, 2003).

Piptadenia gonoacantha (Leguminosae-Mimosoideae) is an arboreal species found predominantly the south and southeast Brazil. It has also been described in some northern and northeastern states. This species is easily identified by its thorny longitudinal woody wings along the trunk and branches. This gives its popular names like alligator wood, alligator, alligator hull, among others (Carvalho et al., 2010). Phytochemical studies have identified several compounds in the leaves of this plant as anthraquinones, phenolics, tannins, saponins, coumarins and flavonoids. The presence of these compounds has been associated with antioxidant, anticarcinogenic, anti-inflammatory, antimicrobial and antiparasitic properties.

This study aimed to determine the phytochemical profile of $P$. gonoacantha leaves and evaluate their in vitro anthelmintic activity against Panagrellus sp. and in vivo toxicity on $\mathrm{Balb} / \mathrm{C}$ mice biochemical, hematological and histological parameters after oral administration of aqueous extract daily for ten consecutive days.

\section{MATERIAL AND METHODS}

\section{Plant material}

One kilogram of fresh $P$. gonoacantha leaves was harvested in Viçosa, located in the state of Minas Gerais, Brazil, $20^{\circ} 45^{\prime} 14$ "S and $42^{\circ} 52$ '55" W, in November 2014, in the spring season. The material was identified and deposited at the Federal University of Viçosa Botanical Garden, voucher specimen $\# 35$,530. Leaves were selected, cleaned and dried at $40^{\circ} \mathrm{C}$ with forced air circulation until dehydration. The dried material was then grounded in a cutting mill.

\section{Extracts preparation}

Aqueous extracts of $P$. gonoacantha leaves were prepared at the concentration of $20 \mathrm{~g} .200 \mathrm{~mL}^{-1}(\mathrm{w} / \mathrm{v})$ by maceration (EAM), ultrasonication (EAU) and lyophilization (EAL) in order to validate the best extraction method. EAM was obtained after $1 \mathrm{~h}$ at room temperature, and the EAU, obtained under the same conditions, however, subjected to ultrasound (Unique ${ }^{\circledR}$ MaxiClean 1400), following methodology used by Carvalho et al. (2011). Extracts were filtered separately under vacuum to remove completely dry matter, obtaining maximum solution volume. After filtration, $200 \mathrm{~mL}$ of EAU was lyophilized to obtain EAL.

\section{Phytochemical tests}

Phytochemical evaluation was carried out in all extracts produced from $P$. gonoacantha leaves. They were subjected to a series of chromatic and precipitation reactions, according to methods described by Simões et al. (1999) and to characterize the secondary compounds classes, such as naphthoquinone (acid/base reaction), flavonoids (cyanidin and sulfuric acid reaction), tannins (reaction with iron salts, precipitation of proteins), coumarins (observation under ultraviolet light), phenolic compounds (FolinCiocalteu reaction), triterpenes and steroids (LiebermannBurchardreaction), glycosides cardiotonics identification (Baljet test and Kedde test), characterization of saponins (LiebermanBuchardreaction and foam index) and alkaloids presence identification (Mayer, Hager and Gragendorff reagents. The phytochemical screening was performed in triplicate.

\section{Helminths mobility assay}

Motility test was conducted according to Cunha et al. (2003). Panagrellus sp. were incubated in oat-water medium culture in Petri plates. Then they were removed from the plate, wrapped in surgical gauze and placed in Griffin beakers containing the water at room temperature. After $12 \mathrm{~h}$, the Panagrellus sp. pellet was recovered from the beaker and washed three times by re-suspension in distilled water followed by centrifugation at $250 \mathrm{~g}$ and $20^{\circ} \mathrm{C}$ for $5 \mathrm{~min}$. Active and inactive Panagrellus sp. were identified and counted under light microscopy according to Barçante et al. (2003) with modifications. A volume of $0.5 \mathrm{~mL}$ of the nematoid suspension (2000 Panagrellus sp.) and $1.5 \mathrm{~mL}$ of the $P$. gonoacantha extract were added to each well of a 24-well culture plate.

Three concentrations $(25,50$ and $100 \mathrm{mg} \cdot \mathrm{mL}-1)$ of each preparation (EAM, EAU, and EAL). As positive and negative controls, $2 \%$ fenbendazole and distilled water were used, respectively. Six replicates were performed for each preparation. Living and dead larvae counts in $100 \mu \mathrm{L}$ aliquots were performed after 24, 48 and $72 \mathrm{~h}$ of incubation. Dead individuals were identified by the lack of motility. The results were plotted as percentages.

\section{Animals}

Sixty-day-old female Balb/C mice (25-35 g) were obtained from the Central Animal Facility of UFV. The animals were kept under controlled environmental conditions at $23 \pm 2{ }^{\circ} \mathrm{C}$, $12 \mathrm{~h}$ of light/dark cycle, commercial food (Presence ${ }^{\circledR}$ ) and water $a d$ libitum. The methods used in this study was approved by the Ethics Committee for the Use of Animals of the School of Biological and Health Sciences - CEPEUA/FACISA \#106/2014-II. The animals were randomly distributed into five groups with five animals each and received $0.5 \mathrm{mg} \cdot \mathrm{kg}^{-1} \mathrm{PO} /$ day of the flowing compounds per group: Ivermectin (IVE) $1 \%$ (w/v) (positive control); distilled water (negative control); and $P$. gonoacantha leaf aqueous extract (EAU) at 100, 200 or $400 \mathrm{mg}^{\mathrm{kg}} \mathrm{kg}^{-1}$. After ten days, the animals were euthanized by an anesthetic overdose of sodium thiopental. Blood, intestine, liver and kidney were harvested for analysis.

\section{Haematological and biochemical analysis}

For the evaluation of parameters hematological and biochemical characteristics of blood animals, the methodology described by Vasconcelos et al. (2007) with modifications. Blood samples were obtained by cardiac puncture and placed in tubes 
with HB anticoagulant $\left(\right.$ Laborlab $\left.^{\circledR}\right)$ for hematologic analysis and without anticoagulant for biochemical analysis. The values for erythrocytes, leukocytes, platelets, hemoglobin, hematocrit, erythrocyte indices such as mean corpuscular volume (MCV), mean corpuscular hemoglobin $(\mathrm{MCH})$ and mean corpuscular hemoglobin concentration (MCHC) were determined using an automated analyzer of hematologic cells, Human Count (Human do Brasil LTDA ${ }^{\circledR}$ ). Leukocyte count was performed on smears stained with Romanowsky stain under an light microscope. In each slide, 100 cells were analyzed and counted. By biochemical analysis, the following parameters were obtained: aspartate aminotransferase (AST), alanine aminotransferase (ALT), alkaline phosphatase (ALP), total protein, total cholesterol, triglycerides, and urea. The tests were carried in automatic machine Huma Star 300 (Human do Brasil LTDA ${ }^{\circledR}$ ) with Labtest $^{\circledR}$ commercial systems.

\section{Histopathology}

After necropsy, intestine, liver and kidney were removed, washed with saline $(0.9 \%)$ and fixed in formalin buffered at $10 \%$ for 24 hours. Subsequently, the material was subjected to histological techniques, including dehydration in ascending series of alcohols, clearing in xylol and embedding in paraffin $\left(58 \pm 2^{\circ} \mathrm{C}\right)$. Then, $5 \mu \mathrm{m}$-thick sections were obtained in a manual rotation microtome (American Optical Company ${ }^{\otimes}$, United States of America) and subsequently stained with hematoxylin-eosin (HE) (Grimaldi Son, 1981). The following parameters were evaluated: Liver -inflammatory infiltrate, vacuolization, hyperemia, fibrosis, degeneration, and necrosis; Kidney -sclerosis, glomerular shrinkage, inflammatory infiltrate, tubular degeneration and necrosis, fibrosis, and hyperemia; Intestine- edema, hyperemia and inflammatory infiltrate. A score scale from 0 to 3 were considered to all parameters: 0 - absence of injury; 1 - mild injury (up to $25 \%$ ); 2 - moderate injury ( 25 to $50 \%$ ); and 3 - severe lesions (more than 50\%) (Biondo-Simoes et al., 2006). Histological interpretations were performed at Pathology Laboratory of the Department of Veterinary/UFV by two examiners without prior knowledge of the study groups. Micrographs were obtained in the Laboratory of Pathology of the Medicine and Nursing Department/UFV, using a light microscope BX 41 (Olympus ${ }^{\circledR}$, Tokyo, Japan).

\section{Data analysis}

ANOVA was performed to analyze parametric data and Kruskal-Wallis for nonparametric data. As a post-hoc analysis, Student-Newman-Keuls test was used. A 5\% level of significance was considered for all statistical tests.

\section{RESULTS AND DISCUSSION}

Phytochemical profile of the three preparations of $P$. gonoacantha leaf aqueous extract is described in Table 1. The same chemical compounds were detected in all three preparations. Thus, the phytochemical analysis revealed the presence of flavonoids, phenolics, tannins, anthraquinone, saponins, coumarins, and cardiotonic glycosides. Carvalho et al. (2014) evaluated hydroalcoholic compounds at $80 \%(\mathrm{v} / \mathrm{v})$ extracted from $P$. gonoacantha leaves and found the same compounds, corroborating results presented here. According to Leão (2007), such compounds are called secondary metabolites and are related to the chemical plant defense, guaranteeing their survival in their natural habitat. Furthermore, those compounds present a wide diversity and their presence in a given solution will depend on the extraction process and extraction solution used (Alawa et al., 2003).

Typically, alcoholic solutions are more effective than aqueous solutions in the extraction process, being able to solubilize compounds with low and high polarity (Chaicouski et al., 2014). Aqueous preparations only allow obtainment of high solubility compounds such as glycosides, tannins, and alkaloids (Fonseca et al., 2005). However, alkaloids were not found in this study.

Table 1: Phytochemical prospection of Piptadenia gonoacantha leaf aqueous extract.

\begin{tabular}{ccccc}
\hline Compound & Method & EAM & EAU & EAL \\
\hline Alkaloids & Dragendorff & - & - & - \\
& Hager & - & - & - \\
& Mayer & - & - & - \\
Anthraquinones & Borntrager & + & + & + \\
& Magnesium acetate & + & + & + \\
Coumarins & Potassium hydroxide & + & + & + \\
Phenolic & Fólin-ciocalteau & + & + & + \\
compounds & & & & \\
Flavonoids & Aluminum chloride & + & + & + \\
Cardiotonich & Ferric chloride & + & + & + \\
eterosides & Baljet & + & + & + \\
Tannins & Lead acetate & + & + & + \\
Saponins & Libermann-burchard & + & + & + \\
\hline EAM: & Aqueous &
\end{tabular}

EAM: Aqueous extract, macerated; EAU: Aqueous extract, ultrasonicated EAL: Aqueous extract, lyophilized. (+) Present; (-) Absent.

To evaluate nematicidal properties, toxic activity on Panagrellus sp. of different $P$. gonoacantha leaf preparations was evaluated by mobility assay. Although they are not parasitic, they are used as an experimental model because they can be maintained and multiplied in laboratory conditions (Katiki et al., 2011). Thompson et al. (1996) reported that the effectiveness of preparations evaluated in low concentrations against this species, it is possible that they have anthelmintic activity against other nematodes.

In this study, after 24 hours of incubation, all preparations of the extract (EAM, EAU, EAL) showed nematicida laction on Panagrellus sp. with the same efficacy as the control groups (Figure 1 and 2). In absolute terms, EAU at $50 \mathrm{mg} / \mathrm{mL}$ showed the highest inhibition percentage, reaching $99.88 \%$. However, all the concentrations showed inhibition above 93.0\%, while in control groups there was no larvae inhibition during the first 24 hours 


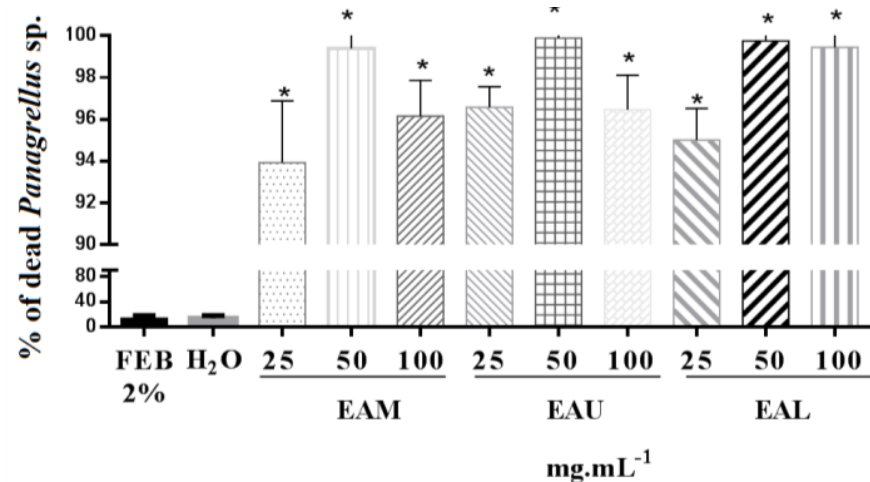

Fig. 1: Mobility assay: effect of Piptadenea gonoacantha leaf aqueous extract on Panagrellus sp. after 24-hour incubation. FEB 2\%: Febemdazole 2\%; $\mathbf{H}_{2} \mathbf{O}$ : Destiled water; EAM: $P$. gonoacantha powder macerated with water; EAU: Ultrasonicated aqueous extract of $P$. gonoacantha; EAL: aqueous extract of $P$. gonoacantha, lyophilized and resuspended in distilled water. Columns represent mean values and standard deviation $(n=6)$. ${ }^{*} \mathrm{p}<0.05$ : significant difference when compared to control groups. Kruskal-Wallis test StudentNewman-Keuls and as post-hoc test.

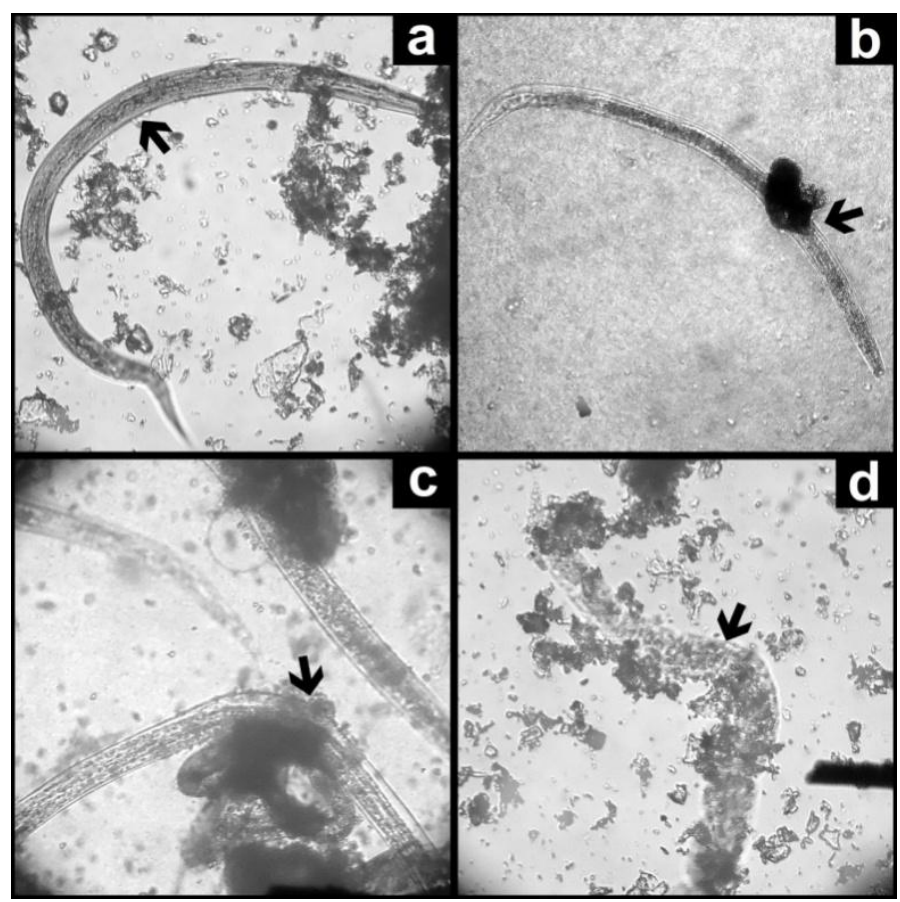

Fig. 2: Effect of ultrasonic aqueous extract (EAU - $50 \mathrm{mg} / \mathrm{mL}$ ) on Panagrellus sp. (A) Panagrellus sp. after 48-hour incubation (negative control - distilled water). (B) Panagrellus sp. after 24-hour incubation. (C) Panagrellus sp. after 48-hour incubation. (D) Effect of $2 \%$ fenbendazole on Panagrellus sp. after 48hour incubation. (A, C and E: 400x.

Among the extraction methods evaluated, EAM presented as an efficient and affordable alternative to be used in helminthes control. The preparation of medicinal species in water is a commonly used practice in folk medicine and its use as a natural vermifuge is becoming more popular as an alternative method, sustainable and adaptable for rural communities (Alawa et al., 2003; Fonseca et al., 2005; Bizimenyera et al., 2006). However, aiming to obtain a formulation for large-scale industrial production, lyophilized extract is presented as a more acceptable formulation because it provides greater physical, chemical and microbial stability, and facilitates homogenization and standardization of the active ingredients (Runha et al., 2001; Chaicouski et al., 2014).

At light microscopy, most of the larvae Panagrellus sp. in the negative control wells showed to be viable throughout the evaluation period, i.e., after 72 hours (Figure 2a). In contrast, $P$. gonoacantha leaf extract led to helminth membrane perforation, resulting in occasional leakage of internal contents and causing lysis after $24 \mathrm{~h}$ of incubation (Figure $2 \mathrm{~b}$ ). After $48 \mathrm{~h}$ of incubation with the extract, the outer membrane of the larvae showed fragility along all its extension (Figure 2c). All preparations and concentrations showed $100 \%$ of the larvae lysed. However, after $48 \mathrm{~h}$ of incubation, Panagrellus sp. larvae used in the positive control become unfeasible. Incubation with fenbendazole, positive control, led to the dissolution of the cuticle of the larvae, making it impossible to evaluate and score (Figure 2d).

In the present study, the extracts were able to effectively inhibit the larvae of Panagrellus sp. Cunha et al. (2003) studied the action of the methanolic extract obtained from the leaves of Leucaena leucocephala, that belongs to the same family of $P$. gonoacantha (Leguminosae - Mimosoideae), and verified the induction of mortality in $98.69 \%$ of Panvitllus redivivus. In the same work, the extract was submitted to a phytochemical identification, which indicated that the nematicidal substance produced by L. leucocephala belongs to the class of alkaloids. Silva et al. (2003) also associated the presence of alkaloids with the destruction of intestinal parasites larvae in the environment. Thus, although this compound was not found in the phytochemical analysis performed in this work, its presence in the leaves of $P$. gonoacantha cannot be ruled out, since its absence may be due to the extraction process used. On the other hand, it can be inferred that the presence of other secondary metabolites is related to the lysis verified under light microscopy. According to Oliveira et al. (2011), the active compounds of plants have been widely studied for the control of intestinal parasites, emphasizing the tannins, which are the secondary metabolites most found in plants. In their condensed form, tannins have the ability to bind and alter physicochemical properties of proteins (Hoste et al., 2006). Therefore, plants in which phytochemical composition contains tannins have a high potential for larval motility inhibition and sheath destruction (Hoste et al., 2006; Nery et al., 2009).

Santos et al. (2013) have shown that the parasites cuticle is rich in proline and hydroxyproline, not only on its external face but also in the oral cavity, esophagus, cloaca, and vulva. These authors emphasize that cuticular changes can be observed under electron microscopy after incubation of nematodes with extracts containing tannins, which corroborates the findings of this research. The nematicidal action of tannins is closely related to the ability to bind and inhibit proteins and enzymes involved in secretory, excretory and metabolic activities, essential for the life of nematodes (Athanasiadou et al., 2001). However, according to Githiori et al. (2005), this action may vary according to the plant species, parasite and host involved. 
Table 2: Analysis of the biochemical parameters of the Balb/C mice, treated with EAU obtained from Piptadenia gonoacantha leaves.

\begin{tabular}{|c|c|c|c|c|c|}
\hline \multirow[b]{2}{*}{ Parameters } & \multirow[t]{2}{*}{ Ivermectin 1\% } & \multirow[t]{2}{*}{ Water } & \multicolumn{3}{|c|}{ EAU $\left(\mathrm{mg}^{\prime} \mathrm{kg}^{-1}\right)$} \\
\hline & & & 100 & 200 & 400 \\
\hline$\overline{\mathbf{A L B}\left(\mathrm{mg} \cdot \mathrm{dL}^{-1}\right)}$ & $4.92 \pm 0.64^{\mathrm{a}}$ & $5.1 \pm 0.76^{\mathrm{a}}$ & $8.44 \pm 2.36^{\mathrm{a}}$ & $5.54 \pm 0.75^{\mathrm{a}}$ & $6.42 \pm 0.87^{\mathrm{a}}$ \\
\hline AST $\left(U . L^{-1}\right)$ & $349.5 \pm 185.18^{\mathrm{a}}$ & $418.2 \pm 61.42^{\mathrm{a}}$ & $443 \pm 90.67^{\mathrm{a}}$ & $450.4 \pm 24.72^{\mathrm{a}}$ & $471.6 \pm 76.66^{\mathrm{a}}$ \\
\hline $\operatorname{ALT}\left(U \cdot L^{-1}\right)$ & $130.8 \pm 43.77^{\mathrm{a}}$ & $96 \pm 10.98^{\mathrm{a}}$ & $77.8 \pm 8.95^{\mathrm{a}}$ & $82.8 \pm 21.07^{\mathrm{a}}$ & $103.2 \pm 23.41^{\mathrm{a}}$ \\
\hline COL $\left(\mathrm{mg} \cdot \mathrm{dL}^{-1}\right)$ & $123.42 \pm 30.65^{\mathrm{a}}$ & $125.4 \pm 15.45^{\mathrm{a}}$ & $100.2 \pm 43.77^{\mathrm{a}}$ & $138.8 \pm 37.04^{\mathrm{a}}$ & $93.6 \pm 22.02^{\mathrm{a}}$ \\
\hline $\operatorname{ALP}\left(U . L^{-1}\right)$ & $85.62 \pm 27.10^{\mathrm{a}}$ & $31.58 \pm 6.56^{\mathrm{a}}$ & $70.02 \pm 23.28^{\mathrm{a}}$ & $83.28 \pm 32.57^{\mathrm{a}}$ & $53.86 \pm 14.80^{\mathrm{a}}$ \\
\hline TRI (mg.dL $\left.{ }^{-1}\right)$ & $193.8 \pm 25.18^{\mathrm{a}}$ & $117.75 \pm 3.97^{\mathrm{a}}$ & $191.2 \pm 287.58^{\mathrm{a}}$ & $119 \pm 9.23^{\mathrm{a}}$ & $117.8 \pm 17.96^{\mathrm{a}}$ \\
\hline URE $\left(\mathrm{mg} \cdot \mathrm{dL}^{-1}\right)$ & $85.2 \pm 12.88^{\mathrm{a}}$ & $66.6 \pm 15.85^{\mathrm{a}}$ & $50.8 \pm 5.22^{\mathrm{a}}$ & $56.8 \pm 11.69^{\mathrm{a}}$ & $50.2 \pm 4.74^{\mathrm{a}}$ \\
\hline
\end{tabular}

ALB: albumin. AST: aspartate aminotransferase. ALT: alanine aminotransferase. COL: total cholesterol. ALP: alkaline phosphatase. TRI: triglycerides. URE: urea. Values represent the mean \pm mean $(n=5)$. Kruskal-Wallis and Student-Newman-Keuls Method as post-hoc test, $\alpha=5 \%$.a. Values followed by equal letters on the line do not differ from each other.

Table 3: Hematological analysis of Balb/C mice treated with EAU obtained from Piptadenia gonoacantha leaves.

\begin{tabular}{|c|c|c|c|c|c|}
\hline \multirow[b]{2}{*}{ Parameters } & \multirow[t]{2}{*}{ Ivermectin 1\% } & \multirow[t]{2}{*}{ Water } & \multicolumn{3}{|c|}{ EAU (mg.kg $\left.{ }^{-1}\right)$} \\
\hline & & & 100 & 200 & 400 \\
\hline$\overline{\operatorname{RBCs}\left(\mathrm{mm}^{3}\right)}$ & $8.27 \pm 1.66^{\mathrm{a}}$ & $8.76 \pm 0.24^{\mathrm{a}}$ & $8.62 \pm 0.38^{\mathrm{a}}$ & $10.18 \pm 0.47^{b}$ & $9.83 \pm 0.30^{\mathrm{b}}$ \\
\hline Hematocrit $(\%)$ & $40.21 \pm 9.64^{\mathrm{a}}$ & $47.43 \pm 1.79^{\mathrm{a}}$ & $42.91 \pm 1.90^{\mathrm{a}}$ & $50.52 \pm 2.86^{\mathrm{a}}$ & $48.95 \pm 1.96^{\mathrm{a}}$ \\
\hline Hemoglobin(g/dL) & $11.75 \pm 2.68^{\mathrm{a}}$ & $14.15 \pm 0.60^{\mathrm{a}}$ & $13.10 \pm 0.53^{\mathrm{a}}$ & $14.25 \pm 0.22^{\mathrm{a}}$ & $13.87 \pm 0.44^{\mathrm{a}}$ \\
\hline MCHC (\%) & $25.83 \pm 5.73^{\mathrm{a}}$ & $29.90 \pm 0.76^{\mathrm{a}}$ & $30.53 \pm 0.58^{\mathrm{a}}$ & $28.36 \pm 1.08^{\mathrm{a}}$ & $28.42 \pm 0.68^{\mathrm{a}}$ \\
\hline $\mathbf{M C H}(\mathrm{pg})$ & $12.78 \pm 2.75^{\mathrm{a}}$ & $16.18 \pm 0.73^{\mathrm{b}}$ & $15.2 \pm 0.28^{\mathrm{b}}$ & $14.02 \pm 0.45^{\mathrm{a}}$ & $14.11 \pm 0.25^{\mathrm{a}}$ \\
\hline $\operatorname{MCV}(\mathrm{fL})$ & $43.37 \pm 10.06^{\mathrm{a}}$ & $54.16 \pm 2.51^{\mathrm{a}}$ & $50 \pm 1.37^{\mathrm{a}}$ & $49.5 \pm 1.15^{\mathrm{a}}$ & $49.87 \pm 1.20^{\mathrm{a}}$ \\
\hline Total leukocytes $\left(\mathrm{mm}^{3}\right)$ & $3.00 \pm 0.78^{\mathrm{a}}$ & $3.57 \pm 0.76^{\mathrm{a}}$ & $2.58 \pm 0.19^{\mathrm{a}}$ & $2.84 \pm 0.22^{\mathrm{a}}$ & $3.81 \pm 0.13^{\mathrm{a}}$ \\
\hline Lymphocytes $(\%)$ & $84 \pm 2.03^{\mathrm{a}}$ & $80.66 \pm 1.32^{\mathrm{ab}}$ & $80.37 \pm 3.26^{\mathrm{ab}}$ & $80.62 \pm 1.58^{\mathrm{ab}}$ & $76 \pm 2.58^{\mathrm{b}}$ \\
\hline Neutrophils $(\%)$ & $12.5 \pm 1.46^{\mathrm{a}}$ & $16.83 \pm 1.91^{\mathrm{a}}$ & $19.12 \pm 6.58^{\mathrm{a}}$ & $15.75 \pm 1.80^{\mathrm{a}}$ & $20 \pm 3.07^{\mathrm{a}}$ \\
\hline Monocytes(\%) & $3.25 \pm 0.81^{\mathrm{a}}$ & $2.88 \pm 0.24^{\mathrm{a}}$ & $2.62 \pm 0.74^{\mathrm{a}}$ & $3.37 \pm 1.14^{\mathrm{a}}$ & $4.25 \pm 0.67^{\mathrm{a}}$ \\
\hline
\end{tabular}

EAU: Aqueous extract, ultrasonicated; MCHC: mean corpuscular hemoglobin concentration; MCH: mean corpuscular hemoglobin; MCV: mean corpuscular volume. Values represent the mean \pm mean standard error $(n=5)$. a.b. Values followed by distinct letters on the line differ from each other. Kruskal-Wallis test and Student-Newman-Keuls as post-hoc test, $\alpha=5 \%$.

As with tannins, flavonoids may also be related to the antihelmintic activity (Silva et al., 2009; Bastos et al., 2014). These are heteroside compounds and constitute a large group of plant pigments widely distributed in nature (Arantes et al., 2005). They have the capacity to form complexes with soluble extracellular proteins and, due to their lipophilic character, promote the rupture in the membrane of several microorganisms, among them the parasites (Sartori, 2005). Therefore, the evaluation of the nematicidal effect of the leaves of $P$. gonoachanta should still be the object of future research, aiming to fractionate and quantify the chemical compounds obtained in different forms of extraction and to verify if this activity depends on a single active substance or a combination of various substances and their concentrations. In addition, works using electron microscopy may help in understanding the mechanism of action of these compounds, especially on the membrane of these organisms. The toxicity of $P$. gonoachanta was also evaluated in vivo. However, no significant changes were observed $(\mathrm{p}>0.05)$ (Table 2). Among transaminases, ALT is considered the most specific to assess liver damage (Giannini et al., 2005). Since the liver is the main organ of degradation of the drug, it can cause damage to the membrane of the hepatocytes promoting the increase in the levels of the enzyme (Rocha et al., 2012). However, according to Qureshi et al. (2013), biochemical changes induced by ivermectin are difficult to explain and are associated with the mechanisms responsible for their antiparasitic activity. The quantitative and qualitative evaluations of blood elements, a significant increase $(\mathrm{p}<0.05)$ was observed in red blood counts of animals treated with EAU at 200 and $400 \mathrm{mg}$.
$\mathrm{Kg}^{-1}$, respectively, when compared to animals from the other groups. Comparing the values of mean corpuscular hemoglobin (HCM), the difference was between the animals belonging to the negative control group and the group treated with ivermectin $1 \%$, compared to the animals from the other treatments (Table 3). Significant difference $(p<0.05)$ was also observed in the percentage of lymphocytes when compared to the animals belonging to the group treated with ivermectin $1 \%$ and with EAU $400 \mathrm{mg} \cdot \mathrm{Kg}^{-1}$. Animals treated with the drug had a higher amount of these cells. According to Bonamin and Paulino (1996), drugs such as levamizol and ivermectin can be used as immunomodulators because they are capable of promoting an increase in the induction of $\mathrm{T}$ lymphocyte proliferation, increased chemotaxis and phagocytic activity. On the other hand, the decrease of these cells in the group treated with the highest dose of the extract can be explained, according to Melo et al. (2008), due to the greater amount of tannins ingested by the animals, since this compound is responsible for the decrease in the total number of lymphocytes. In addition, the anti-inflammatory activity of hydroalcoholic extracts produced from the plant leaves was previously demonstrated in studies carried out by Carvalho et al. (2014), justifying the decrease of these cells. Significant histopathological alterations $(\mathrm{p}<0.05)$ were found only in animals treated with ivermectin $1 \%$. Animals belonging to the other groups did not present relevant histopathological findings (Table 4). Hepatic lesions were characterized by vacuolization of hepatocytes and presence of inflammatory infiltrates, with polymorphonuclear cells predominance. In the kidneys, the presence of glomerular infiltrate and tubular hyperemia were verified. 
Table 4: Histological evaluation of BALB/C mice treated with aqueous extract obtained from Piptadenia gonoacantha leaves, administered orally for 10 consecutive days. Values referring to the average of the scores found.

\begin{tabular}{|c|c|c|c|c|c|c|c|}
\hline & & Lesions & Ivermectin 1\% & Water & & $\mathrm{AU}\left(\mathrm{mg} . \mathrm{kg}^{-}\right.$ & \\
\hline & & & & & 100 & 200 & 400 \\
\hline & & Degeneration/necrosis & $0.2 \pm 0.2^{\mathrm{a}}$ & $0.4 \pm 0.24^{\mathrm{a}}$ & $1.6 \pm 0.4^{\mathrm{a}}$ & $1.0 \pm 0.0^{\mathrm{a}}$ & $1.0 \pm 0.0^{\mathrm{a}}$ \\
\hline & & Fibrosis & $0.6 \pm 0.24^{\mathrm{a}}$ & $0.8 \pm 0.2^{\mathrm{a}}$ & $1.4 \pm 0.24^{\mathrm{a}}$ & $0.8 \pm 0.2^{\mathrm{a}}$ & $0.6 \pm 0.54^{\mathrm{a}}$ \\
\hline Liver & & Hyperemia & $0.8 \pm 0.2^{\mathrm{a}}$ & $0.4 \pm 0.24^{\mathrm{a}}$ & $1.6 \pm 0.4^{\mathrm{a}}$ & $1.0 \pm 0.31^{\mathrm{a}}$ & $1.4 \pm 0.4^{\mathrm{a}}$ \\
\hline & & mimirate & $2.4 \pm 0.24$ & $1.4 \pm 0.24$ & $1.0 \pm 0.4$ & $1.0 \pm 0$ & $1.4 \pm 0.54$ \\
\hline & & Vacuolization & $1.8 \pm 0.37^{\mathrm{b}}$ & $0.4 \pm 0.24^{\mathrm{a}}$ & $0.8 \pm 0.2^{\mathrm{a}}$ & $1.6 \pm 0.24^{\mathrm{a}}$ & $1.2 \pm 0.20^{\mathrm{a}}$ \\
\hline & & Sclerosis & $0.2 \pm 0.2^{\mathrm{a}}$ & $0.4 \pm 0.24^{\mathrm{a}}$ & $0.4 \pm 0.24^{\mathrm{a}}$ & $0.0 \pm 0.0^{\mathrm{a}}$ & $0,0 \pm 0,0 \mathrm{a}$ \\
\hline & Glomerulus & Infiltrate & $1.2 \pm 0.44^{\mathrm{b}}$ & $0.0 \pm 0.0^{\mathrm{a}}$ & $0.4 \pm 0.89^{\mathrm{a}}$ & $0.0 \pm 0.0^{\mathrm{a}}$ & $0,0 \pm 0,0 \mathrm{a}$ \\
\hline & & Retraction & $0.0 \pm 0.0^{\mathrm{a}}$ & $0.0 \pm 0.0^{\mathrm{a}}$ & $0.0 \pm 0.0^{\mathrm{a}}$ & $0.0 \pm 0.0^{\mathrm{a}}$ & $0,0 \pm 0,0 \mathrm{a}$ \\
\hline Kidney & & Infiltrate & $0.6 \pm 0.4^{\mathrm{a}}$ & $1.8 \pm 0.48^{\mathrm{a}}$ & $1.2 \pm 0.48^{\mathrm{a}}$ & $1.0 \pm 0.31^{\mathrm{a}}$ & $2,0 \pm 0,44 \mathrm{a}$ \\
\hline & Tubule & Necrosis / degeneration & $1.4 \pm 0.24^{\mathrm{a}}$ & $1.4 \pm 0.24^{\mathrm{a}}$ & $1.0 \pm 0.44^{\mathrm{a}}$ & $0.6 \pm 0.24^{\mathrm{a}}$ & $0,6 \pm 0,24 \mathrm{a}$ \\
\hline & Tupue & Hyperemia & $1.0 \pm 0.0^{\mathrm{b}}$ & $0.0 \pm 0.0^{\mathrm{a}}$ & $0.6 \pm 0.54^{\mathrm{a}}$ & $0.4 \pm 0.54^{\mathrm{a}}$ & $0,4 \pm 0,54 \mathrm{a}$ \\
\hline & & Fibrosis & $0.0 \pm 0.0^{\mathrm{a}}$ & $0.2 \pm 0.2^{\mathrm{a}}$ & $0.8 \pm 0.48^{\mathrm{a}}$ & $0.0 \pm 0.0^{\mathrm{a}}$ & $0,0 \pm 0,0 \mathrm{a}$ \\
\hline & & Edema & $0.6 \pm 0.24^{\mathrm{a}}$ & $0.2 \pm 0.2^{\mathrm{a}}$ & $0.4 \pm 0.24^{\mathrm{a}}$ & $0.2 \pm 0.2^{\mathrm{a}}$ & $0.6 \pm 0.24^{\mathrm{a}}$ \\
\hline Intestine & & Hyperemia & $0.8 \pm 0.2^{\mathrm{a}}$ & $0.2 \pm 0.2^{\mathrm{a}}$ & $0.8 \pm 0.2^{\mathrm{a}}$ & $0.6 \pm 0.24^{\mathrm{a}}$ & $0.6 \pm 0.24^{\mathrm{a}}$ \\
\hline & & Infiltrate & $1.0 \pm 0.31^{\mathrm{a}}$ & $1.0 \pm 0.54^{\mathrm{a}}$ & $0.4 \pm 0.24^{\mathrm{a}}$ & $0.6 \pm 0.24^{\mathrm{a}}$ & $1.0 \pm 0.31^{\mathrm{a}}$ \\
\hline
\end{tabular}

Values represent the mean \pm mean standard error $(\mathrm{n}=5)$. Values followed by distinct letters on the line differ from each other. Kruskal-Wallis test and Student-

Newman-Keuls as post-hoc test, $\alpha=5 \%$.a.b. Values followed by distinct letters on the line differ from each other.

In the small intestine, although not significant $(\mathrm{p}>0.05)$, it was possible to verify submucosal layer rupture and muscular tunica detachment. Hepatic and intestinal lesions can be justified because ivermectin is mainly metabolized in these organs (Arise $e t$ al., 2012). In a study conducted by Arise et al. (2012), rats treated with an oral combination of ivermectin and albendazole also showed an increase in the polymorphonuclear cells population in the hepatic tissue. Because the organ is the main site of drug detoxification, ivermectin degradation can lead to free radicals production and concentration. Those radicals, when bound to oxygen, can lead to reactive oxygen species formation, capable of causing damage to the membrane and proteins, resulting in a process of cell vacuolization and death (Filho et al., 2006; Dadarkar et al., 2007). In the kidneys, ivermectin $1 \%$ may cause inhibition of renal excretion of various substances (Fricker et al., 1999). According to Whelton et al. (2004), the malfunctioning of glomerular filtration, promotes the retention of substances such as urea, justifying the increase of their levels in the serum of these animals. On the other hand, animals treated with different $P$. gonoacantha EAU doses showed no significant lesions on the liver, kidney, and intestine after acute administration. It may suggest an anthelmintic action without toxicity on those organs. In agreement with this action, the presence of secondary metabolites confer to the EAU antioxidant and anti-inflammatory activity, as demonstrated in previous studies (Pereira et al., 2010; Carvalho et $a l ., 2014)$. However, studies involving the chronic administration of EAU produced from $P$. gonoachanta leaves should be performed so that future clinical trials with target species can be conducted.

\section{CONCLUSION}

Aqueous extracts of $P$. gonoacantha leaves have secondary metabolites with anthelmintic activity, supporting their use in the control of gastrointestinal parasitic diseases of animals. Extracts obtained by ultrasonography prove to be safe due to low toxicity after acute exposure, allowing progress in clinical studies to prove possible benefits in other target species.

\section{ACKNOWLEDGMENT}

Financial support and sponsorship: The authors thank CAPES, FAPEMIG and CNPq for financial support and scholarships.

Conflict of Interests: There are no conflicts of interest.

\section{REFERENCES}

Alawa CBI, Adamu AM, Gefu JO, Ajanusic OJ, Abdu PA, Chiezey NP, Alawa JN, Brwmam DD. In vitro screening of two Nigerian medicinal plants (Vernonia amygdalina and Annona senegalensis) for anthelmintic activity. Vet Parasitol, 2003; 133:73-81.

Arantes VP. Plantas do cerrado brasileiro com atividade contra Mycobacterium fortuitum. J Basic Appl Pharm Sci, 2005; 26:195198.

Arise RO, Malomo SO, Oyewole OI. 2012. Histological changes in selected tissues of ivermectin and/or albendazole treated rats. Int J Toxicol Appl Pharmacol, 2012; 2:1-5.

Athanasiadou S. Direct anthelmintic effects of condensed towards different gastrointestinal nematodes of sheep: in vitro and in vivo studies. Vet Parasitol, 2001; 99:205-219.

Barçante JMP, Barçante TA, Dias SRC, Vieira LQ, Lima WS, Negrão-Corrêa D. A method to obtain axenic Angiostrongylus vasorum first-stage larvae from dog feces. Parasitol Res, 2003; 89:89-93.

Bastos JAR, Pinto R, Pontes KCS, Fausto GC, Carvalho CA, Saraiva LHG. Tratamento Antiparasitário em Bovinos com Erva de Macaé (Leonurus Sibiricus) e Pau Jacaré (Piptadenia gonoacantha) - Uma alternativa terapêutica. In: VI Simpósio de produção acadêmica da faculdade de ciências biológicas e da saúde, 6, 2014, Viçosa. Anais... Viçosa: FACISA, Outubro, 2014.

Biondo-Simões MLP, Alcantara EM, Dallagnol JC, Kelly Okamoto Yoshizum KO, Torresiv LFB, Borsato KS. Cicatrização de feridas: estudo comparativo em ratos hipertensos não tratados e tratados com inibidor da enzima conversora da angiotensina. Rev Col Bras Cir, 2006; 33:74-8

Bizimenyera ES, Githiori JB, Eloff JN, Swan GE.In vitro activity of Peltophoruma fricanum Sond (Fabaceae) extracts on the egg hatching and larval development of the parasitic nematode Trichostrongylus colubriformis. Vet Parasitol, 2006; 142:336-343. 
Bonamin LV, Paulino CA. 1996. Imunofarmacologia. In: Spinosa HS, Górniak SL, Bernardi MM. Farmacologia aplicada à medicina veterinária. Rio de Janeiro, Brasil. Guanabara Koogan 465- 76.

Carvalho MG, Cardozo MA, Catunda Junior FE, Carvalho AG. Chemical constituents of Piptadenia gonoacantha J.F. Macbr. An. $\mathrm{ABC}, 2010 ; 82: 561-567$

Carvalho CD, Moreira FRO, Bezerra KS, Guimarães JVCN, Cardoso JC, Lima AS, Jeraldo VLS, Melo CM. Infecção parasitária e perfil sanitário de plantel caprino em área urbana de Sergipe. Scipl, 2011; 7:1-9.

Carvalho CA, Santana GS, Amaro MOF, Lima LM, Pires FB, PráVD, Cardoso SA, Rosa MB, Oliveira LL. Aspectos químicos e atividade antibacteriana de Piptadenia gonoacantha (FABACEAE). CeN, 2014; 36:732-744

Castro-Sandoval CA, Torres-Acostaa JFJ, Hosteb H, Salemd AZM, Chan-Pérez JI. Using plant bioactive materials to control gastrointestinal tract helminths in livestock. Anim Feed Sci Technol, 2012; 176:192-201.

Chaicouski A, Silva JE, Trindade JLF, Canteri MHG. Determinação da quantidade de compostos fenólicos totais presentes em extratos líquido e seco de erva-mate (Ilexparaguariensis). RBPA, 2014; $16: 33-41$

Cunha FR, Oliveira DF, Campos VP. Extratos Vegetais com Propriedades Nematicidas e Purificação do Princípio Ativo do Extrato de Leucaena leucocephala. FitopatolBras,2003; 28:438-441.

Dadarkar SS, DeoreMD, Gatne MM. Comparative evaluation of acute toxicity of ivermectin by two methods after single subcutaneous administration in rats. Regul Toxicol Phar, 2007; 47:257-60.

Filho GB, Bogliolo L. 2006. Bogliolo Patologia. 7 ed. Rio de Janeiro, Brasil: Guanabara Koogan.

Fricker A, Cutmann H, Droulle A, Drewe J, Miller DS. Epithelial transport of anthelmintic ivermectin: a novel model of isolated proximal kidney tubules. Pharm Res, 1999; 16:1570-1575.

Fonseca SGC. Farmacocinética de Fitoterápicos. 2005. [ONLINE]. Disponível em: http://www.farmacotecnica.ufc.br/.Acesso em: 22 de janeiro de 2015 .

Geary TG, Thompson DP. Development of antiparasitic drugs in the 21st century. Vet Parasitol, 2003; 115:167-184.

Giannini EG, Testa R, Savarino V. Liver enzyme alteration: a guide for clinicians. Can Med Assoc J, 2005; 172:367-79.

Githiori JB, Hoglund J, Waller PJ. Ethnoveterinary plant preparation as dewormers: practices, popular beliefs, pitfalls and prospects for future. Anim Health Res Rev, 2005; 6:91-103.

Grimaldi F. Técnica Histológica. Rio de Janeiro, RJ, 1981.

Hoste H, Jackson F, Athanasiadou S, Thamsborg SM, Hoskin SO. The effects of tannin-rich plants on parasitic nematodes in ruminants. Trends Parasitol, 2006, 22:253-261.

Katikia LM, Ferreira JFS, Zajacc AM, Maslerd C, Lindsayc DS, Chagase AC, Amarante AFT. Caenorhabditis elegans as a model to screen plant extracts and compounds as natural anthelmintics for veterinary use. Vet Parasitol, 2011, 182:264-268.

Leão JDJ. 2007. Bioatividade de extratos vegetais no controle de Sitophilus oryzae (Linné, 1973) em arroz. 91p.

Melo M.M, Júnior DV, Pinto MCL, Silveira JB, Ferraz V, Ecco $\mathrm{R}$, Paes PRO. Intoxicação experimental com extratos de Mascagnia rigida (Malpighiaceae) em camundongos. Arq Bras Med Vet Zootec, 2008; 60:631-640.

Mellor S. Herbs and spices promote health and growth. Pig Progress, 2000; 6:27-30.

Nery OS, Duarte ER, Martins ER. Eficácia de plantas para o controle de nematoides gastrintestinais de pequenos ruminantes: revisão de estudos publicados. Vet Bras P1 Med, 2009; 11:330-338.

Oliveira LMB de, Bevilaqua CML; Morais SM de, Vasconcelos ALFC, Macedo ITF. Plantas taniníferas e o controle de nematóides gastrintestinais de pequenos ruminantes. Cienc Rural, 2011, 41:19671974.

Padilha IQM, Pereira AV, Rodrigues OG, Siqueira-Júnior JP, Pereira MSV. Antimicrobial activity of Mimosa tenuiflora (Willd.) Poir.
From Northeast Brazil against clinical isolates of Staphylococcus aureus. Rev Bras Farmacogn, 2010; 20:45- 47.

Pereira BS, Nunes-Pinheiro DCS, Vasconcelos AKP, Pinheiro ADN, Rodrigues PA. Atividade hepatoprotetora dos extratos etanólico e hexânico das folhas de Momordica charantia L. Rev Bras Plantas Med, 2010; 12:311-316

Qureshi S. Biochemical Toxicity of Ivermectin in Wistar Albino Rats. Amer Eurasian J Toxicol Sci, 2013; 5:15-19.

Ribeiro CM. Avaliação da atividade antimicrobiana de plantas utilizadas na Medicina popular da Amazônia- 2008. 66p. Dissertação (Mestrado) - Programa de Pós Graduação em Ciên Farm. Instituto de Ciências da Saúde. Universidade Federal do Pará, Belém.

Rocha AOB, Pita JCLR, Oliveira KM, Mota CAX, Estevam EC, Viana WP, Sá RCS, Diniz MFFM. Efeito toxicológico do extrato hidroalcoólico de Pradosia huberi Ducke em ratos Wistar. Vet Bras Farm, 2012; 93:371-378.

Runha FP, Cordeiro DS, Pereira CAM, Vilegas J, Oliveira WP. Production of dry extracts of medicinal Brasilian plants by spouted bed process: development of the process and evaluation of thermal degradation during operation. Food Bioprod Process, 2001; 79:169-168.

Santana LCLR, Brito MRM, Sousa GF, Freitas RM. Propriedades físicoquímicas e avaliação da toxicidade aguda do extrato etanólico padronizado a $70 \%$ das folhas de Mikania glomerata (Asteraceae). Vet Bras Pl Med, 2013, 15:742-750.

Santos IA, Souza FJMA, Akisue G, Coelho FAS, Coelho MDG. Avaliação da atividade ovicida e larvicida de dez extratos vegetais ante Ancylostomas pp. Vet Patol Trop,2013; 42:209-21.

Sartori MRK. Atividade antimicrobiana de fração de compostos puros obtidos das flores da Acmela brasiliensis Spreng (Wedelia paludosa) (Asteraceae). 2005, 81p. Dissertação (Mestrado) Ciên Farm. Universidade do Vale do Itajai, Santa Catarina.

Simões CO, Schenkel EP, Gosmão G, Mello JCP, Mentz LA, Petrovick PR. 1999. Farmacognosia da Planta ao Medicamento. $5^{\text {a ed. }}$ Porto Alegre/Florianópolis: Editora UFRGS/ Editora UFSC.

Simões CO, Schenkel EP, Gosmão G, Mello JCP, Mentz LA, Petrovick PR. 2004.Farmacognosia da planta ao medicamento.5.ed., Porto Alegre/Florianópolis: Editora UFRGS, 821p.

Silva NR, Brooker S, Hotez PJ, Montresor A, Engels D, Savioli L. Soil-transmitted helminth infections: updating the global picture. Trend Parasitol, 2003; 19:547-551.

Silva JG, Pereira MSV, Gurgel APD, Siqueira-Júnior JP, Souza IA. Atividade inibitória das folhas e caule de Kalanchoe brasiliensis Cambess frente a microrganismos com diferentes perfis de resistência a antibióticos. Rev Bras Farmacogn, 2009; 19:790-794.

Thompson DP, Klein RD, Geary TG. Prospects for rational approaches to anthelmintic discovery. Parasitol, 1996; 113:217-238.

Vasconcelos THC, Modesto-Filho J, Diniz MFFM, Santos HB, Aguiar FB, Moreira PVL. Estudo toxicológico pré-clínico agudo com o extrato hidroalcoólco das folhas de Cissus sicyoides $L$. (Vitaceae). Braz J Pharmacog., 2007; 17:583-591.

Viegas C Jr, Bolzani, VS, Barreiro EJ. The natural products and the modern medicinal chemistry. Quim Nova. 2006; 29:326-337.

Whelton SP, Chin A, Xin X, He J. Effect of aerobic exercise on blood pressure: a meta analysis of randomizes, controlle trials. Ann Intern Med. 136: 493-503, 2004.

\section{How to cite this article:}

Fausto MC, Nonato IA, Fausto GC, Pinto R, Valente FL, Carvalho LM, Campos AK, Rosa MB, Araújo JV, Carvalho CA. Anthelmintic potential and in vivo acute toxicity study of Piptadenia gonoachanta leaf aqueous extract. J App Pharm Sci, 2017; 7 (10): 111-117. 